Vol. 5, No. 5, 2019

DOI: https://doi.org/10.30525/2256-0742/2019-5-5-197-203

\title{
FISCAL POLICY AND INSTITUTIONAL BUDGET ARCHITECTONICS ${ }^{*}$
}

\author{
Igor Chugunov'1, Valentina Makohon², Tetniana Krykun³
}

\begin{abstract}
The purpose of the article is to study the role of fiscal policy in the context of the development of institutional budget architectonics aimed at ensuring macroeconomic stability, boosting economic growth, strengthening human potential, improving public welfare and defining approaches to its formation in advanced and transition economies. Comparative and factor methods make it possible to cover the peculiarities of institutional environment of the formation of fiscal policy in EU countries and Ukraine in the context of the development of the institutional budget architectonics and to identify ways for its improvement. Methodology. Substantiation of the role of fiscal policy in terms of the development of institutional budget architectonics, determination of its strategic orientations are based on generalization and systematization of experience of advanced and transition economies. For this very reason, the authors analyse and assess the fiscal policy and define special aspects of the formation and implementation of its components in relevant countries. Results show that to increase the effectiveness of the fiscal policy, it is expedient to ensure its interrelation with other components of financial policy based on a combination of fiscal and motivation function. Effective institutional budget architectonics provides means for creating conditions for sustainable economic growth, achieving strategic goals of socio-economic development of the country. Significant tasks of the development of institutional budget architectonics are regulation of the ratio between direct and indirect tax revenues, the structure of budget expenditures in terms of functional, economic classifications, maintaining the budget gap and public debt at the level that contributes to the financial and economic stability of the country, taking into account economic cyclical nature. Practical implications. A feasible budget architectonics would facilitate the maintenance of macroeconomic stability and accelerate economic growth. It is expedient to carry out institutional changes of budget architectonics on the ground of dynamic interconnection of budget and macroeconomic indicators. Value/originality. Fiscal policy plays a significant part in the process of government regulation of socio-economic development of the country. Elaboration of fiscal policy approaches in the context of the development of institutional budget architectonics is an important prerequisite for improving the quality of budget planning, ensuring the strength, stability and dynamic balance of the budget system. It is advantageous to introduce adaptive institutional changes into the budget architectonics in order to accelerate economic growth. Therefore, the article covers the essence and role of institutional budget architectonics aimed at ensuring macroeconomic stability, accelerating economic growth, developing human potential, improving public welfare; it defines the approaches to its development in transition and advanced economies. The authors establish that effective fiscal policy based on feasible institutional budget architectonics provides means for creating conditions for sustainable economic growth, achieving strategic goals of socio-economic development of the country.
\end{abstract}

Key words: fiscal policy, budget system, budget architectonics, budget deficit, government debt.

JEL Classification: E62, H60, O40

\footnotetext{
Corresponding author:

${ }^{1}$ Kyiv National University of Trade and Economics, Ukraine.

E-mail:makvknteu@gmail.com

ORCID: http://orcid.org/0000-0003-4915-1267

${ }^{2}$ Kyiv National University of Trade and Economics, Ukraine.

E-mail:makvknteu@gmail.com

ORCID: http://orcid.org/0000-0002-2331-8455

${ }^{3}$ Research Financial Institute,

Kyiv National University of Trade and Economics, Ukraine.

E-mail: krykun1909@gmail.com

ORCID: https://orcid.org/0000-0003-0355-5768
}

\footnotetext{
* The article is based on R\&D data: "The fiscal strategy of economic growth" (state registration number of the paper 0119U100577); "Fiscal and socio-economic security of the county in the context of hybrid aggression" (state registration number of the paper 0119U100581).
} 


\section{Introduction}

At the current stage of the development of the system of public finance, improvement of the effectiveness of fiscal policy and ensuring its coherence with economic policy necessitates the intensification of the research of approaches to its development based on sound institutional budget architectonics. The use of discretionary and non-discretionary instruments of fiscal policy based on adaptive institutional changes in budget architectonics, taking into account economic cyclical nature, will allow reacting to the influence of endogenous and exogenous factors, changes in the external economic environment and maintaining the economic and financial stability of the state. It is important to define and implement institutional budget architectonics keeping in mind economic cyclical nature, the state of the institutional environment of the formation of fiscal policy based on the optimal balance of budget, tax, social and government debt indicators. The need for adaptive institutional changes in budget architectonics in the current context is due to the instability of the financial and economic context. The above confirms the relevance and timeliness of the research. Thus, the research problem is as follows: what is the role of fiscal policy in the ensuring of macroeconomic stability under transformation changes, what are the orientations of changes of budget architectonics will facilitate the acceleration of economic growth maintaining characteristics of the integral development of the public finance system in general? The paper aims to find out the role of fiscal policy in the context of the development of institutional budget architectonics, generalize and substantiate the approaches to its formation in the advanced and transition economies.

\section{Approaches to the formation of fiscal policy}

The essence of fiscal policy involves the system of measures using which the state influences the economy through the structure of tax payments to the budgets of all levels and state trust funds and their relevant expenditures (Karlin, 2014); the system of economic instruments due to which state administration bodies influence the size of the public and private sectors that determine the aggregate demand and the level of economic activity (Harumová, 2002). The point of budget architectonics is to form budgets of different levels based on the optimal balance of budget, tax, social, monetary and government debt components, which is a dynamic institutional process of elaborating and implementing budget policy in the corresponding socioeconomic conditions of the country's development.

The researches make a hypothesis that the implementation of discretionary fiscal policy creates different expectations about the level of public debt and budget balance (Montes, Luna, 2018). However, it is defined that fiscal policy is predictable, and its consequences depend on the degree of its influence on the expectations (Cavallari, Romano, 2017).

The issues concerning the implementation of the fiscal policy taking into consideration economic cyclical nature are still controversial: studying the cyclical nature of fiscal policy in eleven OECD countries, scholars note that fiscal policy is counter-cyclical in seven of the eleven countries analyzed. At the same time, there is no evidence of pro-cyclical fiscal policy in none of eleven countries (Omar H.M.N. Bashar \& Prasad Sankar Bhattacharya \& Mark E. Wohar, 2017); fiscal policy is countercyclical. Thus, when the debt/GDP ratio exceeds $87 \%$, fiscal policy becomes pro-cyclical (Combes Jean-Louis \& Minea A., \& Sow, 2017).

The budget deficit is a significant instrument of fiscal policy. In particular, one marks that it has a more powerful influence on economic growth than government debt (Kameda, 2014); the negative correlation between the growth of the state budget deficit and the level of economic growth remains. Thus, an important task is to justify sources of its funding (Arjomand, Emami, Salimi, 2016); it is expedient to increase the share of the budget deficit in the gross domestic product to have a countercyclical effect on the economic growth (Taylor, Proaño, Carvalho, Nelson, 2012).

An important task is to reduce public expenditures for the optimization of the level of the budget deficit in the modern context. Research states that fiscal policy measures on the austerity of public resources significantly enhance the economic activity of EU member states. Moreover, the level of impact of public expenditures on economic growth in the EU member states is more significant when joining than in the full member states (Mencingera, Aristovnika, Verbičab, 2017). When evaluating the impact of fiscal policy using public expenditures and taxes on economic growth, it is important to take into account the unemployment rate as the increase in its critical level gradually leads to a higher government multiplier (Biolsi, 2017).

Evaluating the multiplier of short-term investments, it is noted that the built-in stabilizers of fiscal policy can only mitigate but not eliminate the impact of negative exogenous impulses causing cyclical economic downturns (Dupaigne, Fève, 2016); degree of the economic advance can change the effect of the traditional determinants of fiscal multipliers (Hory Marie-Pierre, 2016).

The financial crisis has prompted the need to combine fiscal policy with monetary one (Allard, Catenaro, Vidal Jean-Pierre, Wolswijk, 2013). Components of the financial policy, in particular, monetary and fiscal policies reinforce each other in terms of ensuring macroeconomic stability (Wang, 2018). Consistency of monetary and fiscal policy instruments contribute to the stabilization of government debt (Çebi, 2012). Thus, according to "Fiscal theory of the price level" 
(2008), a significant level of government debt and an unbalanced budget in the long term activate inflationary developments.

\section{Special aspects of fiscal policy in the context of transformational changes}

The intensification of globalization has led to transformational changes focused on creating new financial and economic conditions which refresh the need to advance the efficiency of fiscal policy. Moreover, the level of financial and budget firmness and stability of the majority of the states confirms the importance of applying an adequate system of budgetary regulation, ensuring the dynamic harmony of the state budget as a necessary condition for sustainable economic growth.

The effective institutional budget architectonics is the basis for the implementation of fiscal policy and achievement of its strategic goals. The development of social relations provides for adaptive changes in budget architectonics, taking into account the cyclical nature of economic processes. In particular, in substantiating the objectives of fiscal policy, the important task is to determine the current phase of the economic cycle of the country, calculate the level of potential gross domestic product at which the economy can generate in terms of full-time occupation and the difference between actual gross domestic product and potential one - the GDP gap. In case of a negative GDP gap at which the actual economic growth rate lags behind the potential, it is expedient to realize expansionary fiscal policy and contractionary one under the condition of a positive gap of the gross domestic product based on introducing adaptive institutional changes to budget architectonics.

It is important to note that the special aspects of modern budget architectonics both in advanced and transition economies are determined by: development level of financial-budget institutions; specific nature of budget mechanisms, its methods and instruments; historically contingent part of the public sector of the economy and the level of the tax burden, the development of a system of state welfare activities, which affects the share of GDP redistribution through the budget system.

The above optimum share ratio is different for advanced and transitive economies and depends on economic cyclical nature. The level of fiscal revenue, including tax, primarily influences the aggregate consumption, determines the directions of savings use, and regulates the demand, the structure of manufactured goods and ultimate use. Thus, it ensures the reduction of cyclical fluctuations in the economic development of the country. In addition, a significant level of recovery of funds from economic entities and household sector does not stimulate entrepreneurial activity, which affects the cutback of the rate of manufactured products, the growth of real gross domestic product and, accordingly, the increase of the revenue. The establishment of a low recovery rate reduces budget revenues, which limits the regulatory capacity of fiscal policy. Thus, it is important to determine the optimal level of budget redistribution, taking into account economic cyclical nature and the level of economic growth.

Budget expenditures affect structural changes in the economic sectors, the advancement of human potential and improvement of its quality, equalization of disproportions of socio-economic development of territories. The level of budget expenditures should correspond to the economic capabilities of the society, taking into account socio-economic factors of the national development.

In particular, one of the main reasons for the disruption of fiscal stability in transition economies in the current context is the inconsistency of the rate of growth of the expenditure budget with the rate of economic growth. The transition to sustainable economic growth can be achieved by optimizing budget expenditures through their concentration on priority areas of socio-economic development of countries.

\section{Assessment of budget parameters of EU countries}

In the countries of the European Union, the share of revenues and expenditures in the gross domestic product for $2008-2017$ is $44.45 \%$ and $48.04 \%$ respectively, including $43.89 \%$ and $48.75 \%$ for 2008 - 2012, $45.02 \%$ and $47.32 \%$ for 2013-2017 (Table 1).

To ensure budget balance and sustainability, EU countries take the following measures: the growth in the average rate of increase in tax revenues, including direct taxes and capital taxes; the cut of growth rate of all government expenditures, budget deficit and public debt. At the same time, an important task at this stage is to revise government expenditures in order to reduce them to the Central European level and focus on priority areas of socio-economic development of countries. Thus, the principle of optimization of government expenditures, the size of the budget deficit, and the level of public debt become a significant lever for sound fiscal policy.

The above trends are observed in other countries. Thus, in accordance with the Federal Constitution of the Swiss Confederation, to maintain a balanced structural budget, its expenditures must correspond to cyclicallyadjusted budget revenues, which are calculated on the basis of the anticipated actual budget revenues and the indicator of cyclical phase. This principle of the formation of budget expenditures makes it possible to limit their growth following the counter-cyclical nature of fiscal policy. If the budget deficit passes $6 \%$ on the expenditure side, it will be reduced within three years by cutting the marginal amount of budget expenditures. Through an exception, an increase in expenditures is allowable only under the long and deep financial and economic recession (Geier, 2011). 
Table 1

The share of government expenditures and revenue in GDP in countries of the European Union for 2008-2017, \%

\begin{tabular}{|l|c|c|c|c|c|c|c|c|c|c|}
\hline & 2008 & 2009 & 2010 & 2011 & 2012 & 2013 & 2014 & 2015 & 2016 & 2017 \\
\hline REVENUE & 43.76 & 43.47 & 43.49 & 44.02 & 44.71 & 45.38 & 45.13 & 44.86 & 44.87 & 44.85 \\
\hline Taxes: & 25.92 & 24.91 & 25.15 & 25.59 & 26.14 & 26.52 & 26.58 & 26.65 & 26.72 & 27.77 \\
\hline indirect taxes & 12.59 & 12.46 & 12.82 & 13.03 & 13.27 & 13.34 & 13.43 & 13.43 & 13.40 & 13.38 \\
\hline direct taxes & 12.90 & 12.13 & 12.09 & 12.29 & 12.65 & 12.90 & 12.89 & 12.95 & 13.02 & 13.10 \\
\hline capital taxes & 0.43 & 0.32 & 0.23 & 0.27 & 0.22 & 0.28 & 0.25 & 0.27 & 0.30 & 0.29 \\
\hline Social insurance contributions & 12.97 & 13.47 & 13.25 & 13.29 & 13.37 & 13.45 & 13.36 & 13.18 & 13.37 & 13.33 \\
\hline Sales taxes & 2.87 & 3.09 & 3.13 & 3.12 & 3.12 & 3.18 & 3.15 & 3.09 & 3.07 & 3.06 \\
\hline Capital gains tax & 0.16 & 0.15 & 0.18 & 0.20 & 0.23 & 0.24 & 0.25 & 0.29 & 0.15 & 0.15 \\
\hline Others & 1.84 & 1.84 & 1.78 & 1.83 & 1.85 & 2.00 & 1.80 & 1.65 & 1.55 & 1.54 \\
\hline EXPENDITURES & 46.25 & 50.08 & 49.89 & 48.57 & 48.96 & 48.68 & 48.12 & 47.23 & 46.56 & 46.01 \\
\hline Intermediate consumption & 5.79 & 6.26 & 6.20 & 6.06 & 6.10 & 6.12 & 6.06 & 6.04 & 5.93 & 5.78 \\
\hline Labour renumeration & 10.30 & 11.03 & 10.86 & 10.59 & 10.50 & 10.44 & 10.31 & 10.11 & 10.06 & 9.95 \\
\hline Repayment of interest & 2.69 & 2.58 & 2.67 & 2.89 & 2.87 & 2.70 & 2.54 & 2.27 & 2.14 & 2.04 \\
\hline Subsidies & 1.13 & 1.34 & 1.32 & 1.26 & 1.24 & 1.25 & 1.33 & 1.35 & 1.37 & 1.33 \\
\hline Social aid & 19.07 & 21.20 & 21.11 & 20.79 & 21.09 & 21.31 & 21.22 & 20.93 & 20.98 & 20.78 \\
\hline Others & 2.45 & 2.59 & 2.63 & 2.56 & 2.62 & 2.79 & 2.64 & 2.57 & 2.52 & 2.43 \\
\hline Capital debt transfers & 1.42 & 1.38 & 1.63 & 1.18 & 1.51 & 1.15 & 1.12 & 1.07 & 0.91 & 1.04 \\
\hline Capital investment & 3.40 & 3.71 & 3.47 & 3.24 & 3.03 & 2.91 & 2.89 & 2.89 & 2.66 & 2.66 \\
\hline
\end{tabular}

* It is developed by the authors according to figures of the Official site of the Statistical Office of the European Commission. Retrieved from: http://ec.europa.eu/eurostat

\section{Assessment of budget parameters in Ukraine}

On average, the share of revenues and expenditures of the Consolidated Budget of Ukraine in the gross domestic product is $31.20 \%$ and $34.24 \%$ for $2008-2017$ respectively, including $30.51 \%$ and $33.89 \%$ for $2008-2012,31.88 \%$ and $34.60 \%$ for $2013-2017$ (table 2).

Major portion of expenditures of the Consolidated Budget of Ukraine are for the financing of the sociocultural sphere. Moreover, it is marked the growth in the share of defense expenditures. In the total volume of expenditures, the corresponding figure is $4.58 \%$ for 2008-2017 on average, including $3.18 \%$ for 2008 2012 and 5.97\% for 2013 - 2017. Whereas, in 2016 in the UK, defense expenditures in the overall spending structure were 6.59\% (third place in Europe), 3.52\% in France (seventh place in Europe), 2.58\% - Germany (ninth place in Europe).

Boost of the level of efficiency and effectiveness of budget expenditures necessitates the optimization of their share in each area in the general structure in such a way that their financial and budget architectonics helps to solve the tasks of socio-economic development of the country that provides for ensuring the consistency of the growth of the budget expenditure with the pace of economic growth, objective assessment of the need for each area of the use of budgetary funds and taking into account their impact on the efficiency of socialeconomic processes.

In the structure of the revenue side of the Consolidated Budget of Ukraine as well as in the EU countries, the largest share is for tax revenues. In particular, on average, the share of tax revenues in the consolidated budget revenues of Ukraine amounted to $79.50 \%$ for 2008-2017, including $78.40 \%$ for 2008-2012, and $80.60 \%$ for $2013-2017$. Whereas, in EU countries, the average share of tax collection in state revenues was $58.63 \%$ in $2008-2017$, including $58.19 \%$ in 2008-2012 and 59.07\% in 2013-2017.

It is worth pointing out that the role of indirect taxes is enhanced in Ukraine in the context of economic transformations. The improvement of the effectiveness of their use is conditioned by the need for a balance between internal supply and demand, formation of relevant proportions of consumer market development, ensuring of the growth of competitive capacity of the producer, stimulation of priority economic activities and support of the development of administrative and territorial units. The share of indirect taxes in tax revenues of the consolidated budget of Ukraine was $52.82 \%$ on average for $2008-2017$, including $52.76 \%$ for 2008 - 2012, 52.89\% for 2013-2017. And the corresponding indicator of direct taxes was $47.18 \%$ for 2008-2017, including $47.24 \%$ for 2008-2012, $47.11 \%$ for $2013-2017$.

The share of the consolidated budget deficit in the gross domestic product was $3.12 \%$ for 2008-2017, including $3.40 \%$ for $2008-2012$, and $2.84 \%$ for 2013-2017. A relevant indicator of direct government and guaranteed debt was $50.90 \%$ for $2008-2017$, including $33.52 \%$ for $2008-2012$, and $68.28 \%$ for 2013-2017. Under the increase of the share of direct government and guaranteed debt in the gross domestic product for 2008-2017, the growth in the real gross domestic product decreases by 0.06 percentage points. 
Table 2

The share of revenue, expenditures, deficit of the Consolidated Budget in the GDP, \%

\begin{tabular}{|l|c|c|c|c|c|c|c|c|c|c|}
\hline \multicolumn{1}{|c|}{ Indicators } & 2008 & 2009 & 2010 & 2011 & 2012 & 2013 & 2014 & 2015 & 2016 & 2017 \\
\hline REVENUES & 31.42 & 29.89 & 29.05 & 30.61 & 31.57 & 30.43 & 29.11 & 32.94 & 32.85 & 34.09 \\
\hline Tax revenues & 23.96 & 22.78 & 21.65 & 25.70 & 25.55 & 24.33 & 23.46 & 25.64 & 27.31 & 27.76 \\
\hline Non-tax revenues & 6.38 & 6.39 & 6.82 & 4.61 & 5.73 & 5.84 & 5.14 & 7.08 & 5.27 & 5.18 \\
\hline Capital gains tax & 0.71 & 0.41 & 0.29 & 0.18 & 0.21 & 0.11 & 0.13 & 0.09 & 0.07 & 0.07 \\
\hline $\begin{array}{l}\text { Official transfers from foreign governments } \\
\text { and international organizations }\end{array}$ & 0.01 & 0.07 & 0.03 & 0.04 & 0.01 & 0.10 & 0.34 & 0.10 & 0.18 & 0.05 \\
\hline Trust funds & 0.35 & 0.24 & 0.26 & 0.08 & 0.06 & 0.05 & 0.03 & 0.03 & 0.03 & 1.02 \\
\hline EXPENDITURES & 32.91 & 33.96 & 35.03 & 32.36 & 35.17 & 34.80 & 33.28 & 34.34 & 35.16 & 35.43 \\
\hline Nationwide functions & 3.26 & 3.63 & 4.15 & 3.82 & 3.87 & 4.24 & 4.84 & 5.92 & 5.64 & 5.57 \\
\hline Military defence & 1.23 & 1.06 & 1.04 & 1.01 & 1.03 & 1.02 & 1.72 & 2.62 & 2.49 & 2.49 \\
\hline Public order, security and the judiciary & 2.86 & 2.66 & 2.66 & 2.50 & 2.60 & 2.71 & 2.83 & 2.76 & 3.03 & 2.97 \\
\hline Economic activity & 5.67 & 4.64 & 4.17 & 4.73 & 4.66 & 3.49 & 3.04 & 2.97 & 2.84 & 3.45 \\
\hline Environmental safety & 0.30 & 0.27 & 0.27 & 0.30 & 0.38 & 0.38 & 0.22 & 0.28 & 0.26 & 0.25 \\
\hline Housing and utilities infrastructure & 0.95 & 0.82 & 0.51 & 0.68 & 1.45 & 0.55 & 1.14 & 0.80 & 0.75 & 0.91 \\
\hline Health care & 3.54 & 4.01 & 4.13 & 3.76 & 4.15 & 4.23 & 3.60 & 3.57 & 3.17 & 3.43 \\
\hline Spiritual and physical development & 0.83 & 0.91 & 1.06 & 0.83 & 0.96 & 0.94 & 0.87 & 0.82 & 0.71 & 0.81 \\
\hline Education & 6.42 & 7.31 & 7.37 & 6.63 & 7.20 & 7.25 & 6.31 & 5.74 & 5.43 & 5.96 \\
\hline Social protection and social security & 7.84 & 8.64 & 9.67 & 8.11 & 8.88 & 9.98 & 8.70 & 8.87 & 10.85 & 9.58 \\
\hline BUDGET DEFICIT & -1.43 & -3.93 & -5.77 & -1.71 & -3.48 & -4.18 & -4.54 & -1.55 & -2.30 & -1.40 \\
\hline
\end{tabular}

* It is developed by the authors according to figures of the Official site of Ministry of Finance of Ukraine. Retrieved from: https://minfin.gov.ua.

\section{Strategic targets of the fiscal policy in the context of transformational changes}

Priority targets of fiscal policy at the current stage are as follows: provision of the stability, sustainability and dynamic balance of budgets at different levels based on fiscal constraints, in particular, at the level of government debt and budget deficit; enhancing the efficiency of use of budget funds by ensuring consistency of budget assignments with strategic priorities of socio-economic development of the country, substantiation of efficiency, effectiveness and expediency of budget expenditures; elaboration of provisions on the use of the mechanisms of public-private partnership as a tool reducing the impacts on the budget; raising the level of economic return of the tax system, which envisages creation of favourable conditions for growth of economic activity of undertakings and the economy as a whole, due to its de-shadowing, optimization of the tax potential of territories, introduction of the principles of transparency of entities of tax relations, renewal of confidence between taxpayers and the state, carrying out a comprehensive assessment of the uniformity of the tax burden and the consequences of predicted and conducted fiscal measures, improvement of the monitoring system of major taxpayers, the establishment of balanced criteria and requirements for the provision of tax incentives; intensification of fiscal decentralization processes; advancement of the effectiveness of control and audit in the budget process; development of the system of medium-term budget planning.

An important task is to update the mechanism of management of budget deficit and government debt in the system of financial regulation that envisages the determination of strategic guidelines on the sources of budget funding and the level and structure of debt portfolio. Optimization of budget expenditures should be based on medium- and long-term budgetary forecasting, taking into account macroeconomic indicators and targeted prudential fiscal policy.

Budgetary forecasting plays an important role in providing firmness, stability and balance of the budget system. The use of economic and mathematical modeling in budget forecasting makes it possible to determine reasonable directions for the use of budget funds, identify the factors which can influence the development of the budget system to the fullest extent. Thus, it permits realizing a comprehensive approach when substantiating the directions of fiscal policy and ways for its implementation.

Thus, the formation of effective budget architectonics involves the development of budget strategy aimed at achieving macroeconomic stability, accelerating economic growth and developing human potential. The elaboration of budget strategy provides taking into account the complex of institutional components of the budget space that determine the extension of the budget system for the long run, the opportunities and threats of the internal and external financial and economic environment, strategic objectives of socio-economic development of the country. The priorities of the budget strategy of advanced and transition economies should include the following: guarantee of macroeconomic stability, which involves reducing the deficit of the national budget and maintaining public debt at the economy-safe level; increase of efficiency of use of 
budget funds and economic return of the tax system; consistency of fiscal policy with monetary policy. In transition economies, important objectives are change from expenditure control to results management, development of the system of a medium-term budgetary planning, ensuring coherence of socio-economic, budget and monetary policies, rational formation of a tax revenue system based on reduction of tax pressure and combination of fiscal and incentive function of taxes, expenditure of financial resources through strengthening control over the efficiency of their use, improvement of the system of relations between budgets of different levels in terms of intensification of decentralization processes, maintaining the independence of local budgets, promotion of comprehensive and dynamic development of administrative units.

Being a significant instrument of socio-economic development of the country, the budget strategy will help to activate economic processes, stimulate the development of its priority sectors, accelerate the intensification of production following the level of social development, and provide social support for the least protected segments of the population. At the same time, the budget strategy makes it possible to form budgets of different levels in terms of conformity of budgetary, tax, social and public debt components of fiscal policy.

\section{Conclusions}

In order to promote the substantiation of fiscal policy, it is expedient to ensure its interconnection with other components of financial policy based on the combination of fiscal and motivation function. Effective institutional budget architectonics permits creating conditions for sustainable economic growth, achievement of strategic goals for socio-economic development of the country. In the context of economic transformations, the level of efficiency of the institutional budget architectonics depends on the degree of consistency of its components in the budget strategy. The important tasks of the development of institutional budget architectonics are regulation of the ratio between direct and indirect tax revenues, the structure of budget expenditures in terms of functional, economic classifications, ensuring of the volume of budget deficit and government debt at a level that contributes to the financial and economic stability of the country taking into account economic cyclical nature.

Considering the need to find a good deal of money for servicing government debt and its repayment, it is advisable to develop an economic and mathematical model based on the assessment of the national economy's ability regarding the maintenance of the above so as well as the uses of the loans obtained. It is expedient to carry out the formation of budget architectonics in the part of the public debt relying on the assessment of macroeconomic proportions and relevant socio-economic conditions of social production. The assessment will make it possible to realize fiscal policy based on the reasonable means of the influence on the socio-economic processes. Institutional changes in budget architectonics should be made on the ground of dynamic interrelation of budgetary and macroeconomic indicators. The fiscal policy aimed at changing reproducible proportions, it should combine and coordinate measures of state administration bodies on the influence on the expansion of production of goods and services. Moreover, it requires the targeted implementation of fiscal policy measures to stimulate investment activity, structural restructuring and economic modernization.

Taking into account modern economic transformations, the important tasks are to provide for dynamic system co-ordination and adequate longterm regulatory measures of fiscal policy for changing the internal and external socio-economic environment, a holistic character of assessment of the influence of institutional budget architectonics on the economic growth; increase of the level of economy monetization; determination of a reasonable level of inflation and interest rate to ensure the sustainability of the budget system; refinancing of innovation development.

The importance of further research regarding the above issues is conditioned by the expediency of improving the effectiveness of fiscal policy based on the elaboration of approaches to the development of institutional budget architectonics aimed at ensuring macroeconomic stability, accelerating economic growth, the expanding of human potential, and improving the welfare of the population.

\section{References:}

Harumová, A. (2002). Dane v teórii a praxi. Bratislava: Iura Edition, 240 p.

Karlin, M. (2014). Sotsialna i fiskalna polityka derzhavy: problemy rehionalnoi koordynatsii v umovakh novoho etapu hlobalizatsii [Social and fiscal policy of the state: problems of regional coordination in the conditions of a new stage of globalization]. Demography and Social Economics, 2(22), 34-44. Retrieved from: http://nbuv.gov.ua/ UJRN/dse_2014_2_5

Montes, G., \& Luna, P. (2018). Discretionary fiscal policy and disagreement in expectations about fiscal variables empirical evidence from Brazil. Economic Modelling.

Cavallari, L., \& Romano, S. (2017). Fiscal policy in Europe: The importance of making it predictable. Economic Modelling, 60, 81-97.

Combes, Jean-Louis, Minea, A., \& Sow, M. (2017). Is fiscal policy always counter- (pro-) cyclical? The role of public debt and fiscal rules. Economic Modelling, 65, 138-146. 
Bashar, Omr H.M.N., Bhattacharya, P., \& Wohar, M. (2017). The cyclicality of fiscal policy: New evidence from unobserved components approach. Journal of Macroeconomics, 53, 222-234.

Kameda, K. (2014). Budget deficits, government debt, and long-term interest rates in Japan. Journal of the Japanese and International Economies, 32, 105-124.

Taylor, L., Proaño, C., Carvalho, L., \& Nelson, B. (2012). Fiscal deficits, economic growth and government debt in the USA. Cambridge Journal of Economics, 36, 189-204.

Arjomand, M., Emami, K., Salimi, F. (2016). Growth and Productivity; The Role of Budget Deficit in the MENA Selected Countries. Procedia Economics and Finance, 36, 345-352.

Biolsi, C. (2017). Nonlinear effects of fiscal policy over the business cycle. Journal of Economic Dynamics and Control, 78, 54-87.

Mencingera, J., Aristovnika, A., \& Verbičab, M. (2017). Asymmetric effects of fiscal policy in EU and OECD countries. Economic Modelling, 61, 448-461.

Dupaigne, M., \& Fève, P. (2016). Persistent government spending and fiscal multipliers: The investment-channel. European Economic Review, 89, 425-453.

Hory, Marie-Pierre (2016). Fiscal multipliers in Emerging Market Economies: Can we learn something from Advanced Economies? International Economics, 146, 59-84.

Allard, J., Catenaro, M., Vidal, Jean-Pierre, \& Wolswijk, G. (2013). Central bank communication on fiscal policy. European Journal of Political Economy, 30, 1-14.

Wang, L. (2018). Monetary-fiscal policy interactions under asset purchase programs: Some comparative evidence. Economic Modelling.

Çebi, C. (2012). The interaction between monetary and fiscal policies in Turkey: An estimated New Keynesian DSGE model. Economic Modelling, 29, 1258-1267 p.

Auernheimer, L. (2008). Monetary Policy Rules, the Fiscal Theory of the Price Level, and (Almost) All that Jazz: In Quest of Simplicity. 